\title{
PENERAPAN SISTEM INFORMASI DALAM IDENTIFIKASI SMELLSCAPE DI DESA WISATA PENTINGSARI Implementation of System Information for Identification of Smellscape in Pentingsari Tourism Village
}

\author{
Amandus Jong Tallo ${ }^{1}$,Nami Fitricia Pasaribu² ${ }^{2}$, Asep Syaiful Bahri ${ }^{3}$, Choirul Mubarok ${ }^{4}$ \\ ${ }^{1,4}$ Program Studi Perencanaan Wilayah \& Kota, Universitas Agung Podomoro Jakarta, Indonesia. \\ ${ }^{2,3}$ Program Studi Bisnis Perhotelan, Universitas Agung Podomoro Jakarta, Indonesia. \\ Email Korespondensi: amandus.tallo@podomorouniversity.ac.id
}

DOI: http://dx.doi.org/10.31314/jsig.v2i2.283

Abstract - The development of tourist village based the potential spatial can often being one of the attractions of the sustainable tourism.Tourist village Pentingsari as one of best tourist village in indonesia has variety of activity that can be yielding an odor in order to increase the identity of the area .Odors resulting is either natural or man-made, was arrested by tourists sensory of smell, then will be the basis for a decision tourists to stay and go back to the future. This study attempts to the smell identified the potential to scatter in tourist village Pentingsari, relation with existing and of land use as one of potential in developing tourist village. This study using nearest neabour analysis by identifying the source of the smell survey from morning until night by grid systems in 65. locations. The analysis showed that there is a kind of 4 in village Pentingsari,: the land, tree dung and. rice fields. $60 \%$ areas dominated by agriculture and the scent of trees and soil pollution prevalent in the north to south. villageThe smell of dung berbada only on north and south, village while the rice fields in the south village, only memorize if rice fields there is only at one point in the south.

Keywords: animal, nearest neabour analysis, smelling, rice fields, earth

\begin{abstract}
Abstrak - Pengembangan desa wisata berbasis potensi spasial dapat menjadi salah satu daya tarik pariwisata berkelanjutan. Desa wisata Pentingsari sebagai salah satu desa wisata terbaik di Indonesia memiliki ragam aktivitas yang dapat menghasilkan bau guna meningkatkan identitas kawasan. Bau yang dihasilkan bersifat alami maupun buatan manusia, ditangkap oleh sensori penciuman wisatawan, kemudian akan menjadi dasar keputusan wisatawan untuk tinggal maupun kembali lagi pada masa mendatang.Penelitian ini bertujuan untuk mengidentifikasi potensi pola sebaran bau di desa Wisata Pentingsari, serta keterkaitan dengan penggunaan lahan eksisting sebagai salah satu potensi dalam mengembangkan desa wisata. Penelitian ini menggunakan Nearest Neabour Analysis dengan mengidentifikasi segala sumber bau yang di survai sejak pagi hingga malam hari dengan sistim grid pada 65 titik lokasi. Hasil analisis menunjukan bahwa terdapat 4 macam bau yang ada di desa pentingsari yaitu: tanah, pohon, kotoran hewan dan sawah. $60 \%$ wilayah didominasi oleh pertanian sehingga Aroma pohon dan tanah kotoran merata di wilayah utara hingga selatan desa. Bau kotoran hewan berbada hanya pada di utara dan selatan desa, sedangkan bau sawah hanya di wilayah selatan desa, meningat luasan sawah hanya terdapat pada satu titik di wilayah selatan.
\end{abstract}

Kata kunci: hewan, nearest neabour analysis, penciuman, sawah, tanah 


\section{PENDAHULUAN}

Pengembangan wilayah berbasis potensi, adalah satu solusi dalam meningkatkan ekonomi desa. Sektor pariwisata merupakan salah satu sektor terpenting dalam pengembangan wilayah. Pada tahun 2015 menurut Travel and Tourism Competitiveness Report dari World Economic Forum bahwa Indonesia telah meraih posisi ke 50 dari sektor pariwisata (Meilan, 2016). Pembangunan sektor pariwisata diharapkan dapat memenuhi aspek kerberlanjutan, yang diarahkan pada pemanfaatan sumberdaya (alam, buatan dan manusia) dalam jangka waktu panjang.

Pariwisata merupakan perjalanan seseorang atau kelompok orang ke suatu tempat tujuan yang berbeda di luar tempat kerja atau tempat tinggal sehari- hari untuk berlibur(Santoso, Sugeng, Ilamsyah, Ilamsyah, Abilaji, 2019). Terdapat tiga potensi wisata diantaranya wisata alam(kekayaan alam, pantai gunung, pemandangan, landscape bentang alam), wisata budaya - religi(situs budaya, tarian, akulturasi acara keagamaan baik tangible maupun intagible) dan wisata minat khusus biasanyaa berupa potensi wisata yang dikaryakan oleh pengelola desa wisata(outbound, tracking, kemah).

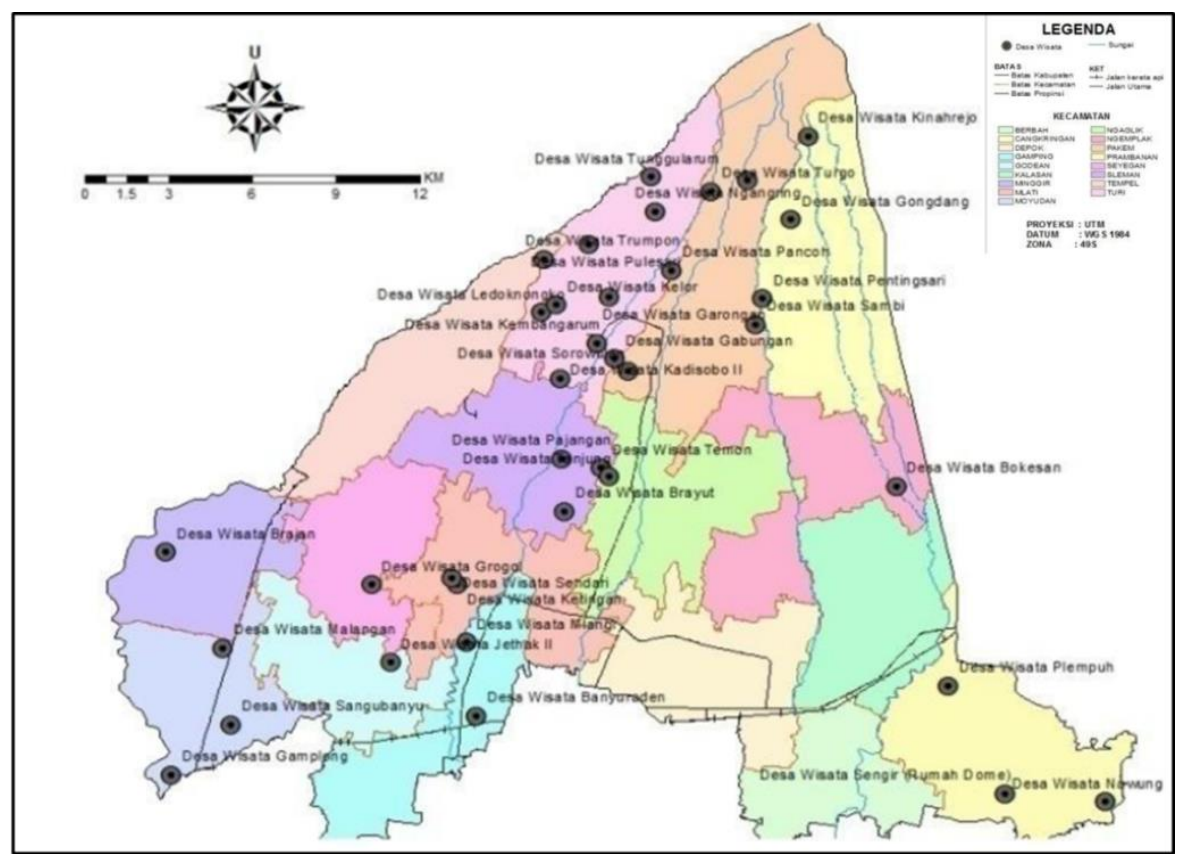

Gambar 1. Persebaran Desa Wisata di Kabupaten Sleman Tahun 2015 (Sumber: Fauzy \& Putra, 2015)

Salah satu metode yang dapat digunakan dalam mengetahui sebaran potensi wisata ialah melalui pemetaan secara spasial .Identifikasi potensi sebaraan objek wisata juga dapat menjadi dasar dalam pengembangan beberapa wilayah pada satu desa, guna perencanaan ke depan. Pada tahun 2015, terdapat 35 titik desa wisata yang tersebaran di 17 kecamatan(Fauzy \& Putra, 2015). Potensi tersebut meningkat pada 2017, sebanyak 28 desa wisata yang didominasi oleh wisata alam sebesar 55,2 \%(Vincentia Reni Vitasurya, Hardiman, \& Sari, 2012).

Potensi wisata pada satu kawasan, sangat bervariasi tergantung karakter masyarakat, lingkungan serta budaya setempat. Keberagaman jenis objek wisata dalam suatu kawasan wisata akan memiliki konsekuensi, terhadap Pengembangan yang dominan di salah satu jenis objek wisata(Sri Rahayu Budiani, Windarti Wahdaningrum, Dellamanda Yosky, Eline Kensari, Hendra S Pratama, Henny Mulandari, Heru Taufiq Nur Iskandar, Mica Alphabettika, Novela Maharani, Rizka Fitria Febriani, 2018). Salah satu objek wisata yang menjadi fokus pengembangan akan menentukan ciri khas dari kawasan.

Perkembangan desa wisata di Yogyakarta mengalami peningkatan sebanyak 43 desa wisata budaya dengan jumlah persebaran terbanyak berada di Kabupaten Sleman(Lestari \& Armawi, 2016). Desa wisata Pentingsari(Dewi Peri) ialah satah satu desa wisata mandiri di Propinsi DI. Yogyakarta, dengan mengandalkan konsep ekowisata berbasis masyarakat. Daya tarik desa wisata Pentingsari adalah kondisi lingkungan alam denganmkeragaman tumbuhan masih lestari 
hingga saat ini (Sucipto, 2019).

Pemanfaatan sistem informasi geografis(SIG) sebagai salah satu teknologi, dapat memberikan gambaran secara vicinal secara spasial maupun nonspasial suatu objek. Teknologi dapat mempermudah akses informasi salah satunya dengan menggunakan dua sistem yaitu sistem informasi geografis dan sistem pendukung keputusan, tata letak objek berbasis peta(Ni Ketut Pradani Gayatri S, Githa, Dwi Putra, 2018). Penggunaan GIS dalam pariwista sebagai alat pendukung pengambilan keputusan dalam perencanaan wisata berkelanjutan, dampak, manajemen arus pengunjung, identifikasi objek wisata sebagai alat disiplin ilmu dalam mengelola, menyimpan, menganalisis dan memvisualisasikan data spasial dan nonspasial(Sugiharto \& Tumiar, 2019).

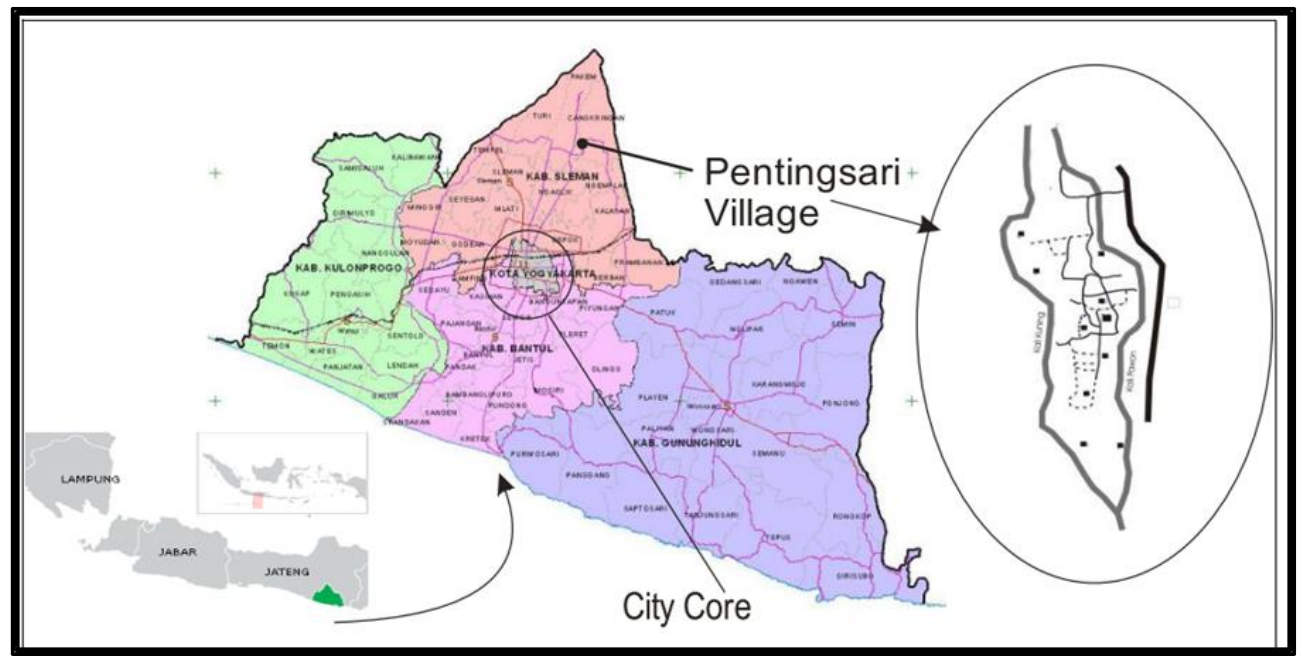

Gambar 2. Peta Orientasi Wilayah Desa Wisata Pentingsari (Sumber :Vitasurya, Pudianti, Purwaningsih, \& Herawati, 2014)

Pemanfaatan GIS secara spesifik dalam pariwisata digunakan untuk mengetahui lokasi destinasi wisata(Agung, Rudi Budi, 2019), perkembangan dan pemantauan objek wisata (Rina Firliana, Patmi Kasih, 2019), infomasi desa wisata dan harga paket wisata(Budiarti, Rike Limia, 2019), pengambilan keputusan terhadap objek wisata yang akan dikunjungi(Anam \& Hartono, 2019), dan sebagainya. Pada prinsipnya SIG dapat membantu menampilkan ragam informasi berbasis lokasi. SIG juga dapat dikombinasikan dengan berbagai perangkat lunak berbasis Android, Website guna memperumah tampilan informasi bagi pengguna.

Informasi terkait potensi wisata, persebaran objek wisata dalam suatu kawasan, jarak tempu menuju kawasan wisata, sering diamati oleh berbagai peneliti dengan memanfaatkan SIG. Salah satu informasi yang jarang ditemukakan adalah bagaimana potensi wisata yang bersifat intagible dapat ditampilkan sebagai salah satu potensi desa wisata. Faktor intagible dalam wisata yang dimasksud adalah elemen-elemen yang tidak kelihatan seperti; presepsi pengunjung, bunyi, bau, daya jual, dan faktor lain non kebendaan, bersifat presepsi. Bau(Aroma) suatu kawasan akan memberikan efek dan presepsi bagi para pengunjung(Gorman, 2017).

Smellscape adalah presepsi akan aroma/bau yan ditimbulkan oleh sensori inderawi(hidung), akan suatu tenpat berdasarkan presepsi dari orang. Aroma yang dihasilkan oleh sumber aroma biasanya berdasarkan dari lingkungan setempat sehingga menimbulkan identitas dari suatu kawasan(Low, 2015). Aroma dapat mempenaruhi presepsi kita akan suatu tempat, bisa linear atau bertentangan(Quercia, Schifanella, Aiello, \& McLean, 2015). Apabila bau tersebut disukai oleh subjek maka dapat bernilai linear, dan sebaliknya, reaksi terhadap bau dapat menimdulkan aksi dari subjek dan juga dapat mempengaruhi kesehatan dari subjek. Penelitian terkait aroma, jarang dilakukan dalam pengembangan desa wisata, padahal efek dari aroma suatu tempat menjukan internaksi simbolik antar pengunjung dengan objek yang dikunjungi. Penelitian ini bertujuan untuk mengidentifikasi sebaran aroma yang ada di desa wisata Pentingsari berbasis sistem informasi geografis. 


\section{METODE DAN DATA}

Secara adminsitratif Desa wisata Pentingsari berada lereng Gunung Merapi tepatnya di

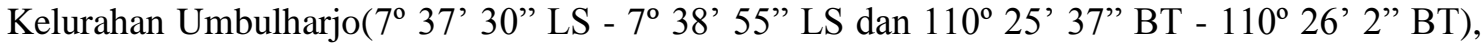
Kecamatan Cangkringan, Kabupaten Sleman, Daerah Istimewa Yogyakarta, dengan ketinggian $550-600 \mathrm{~m} \mathrm{dpl}$.

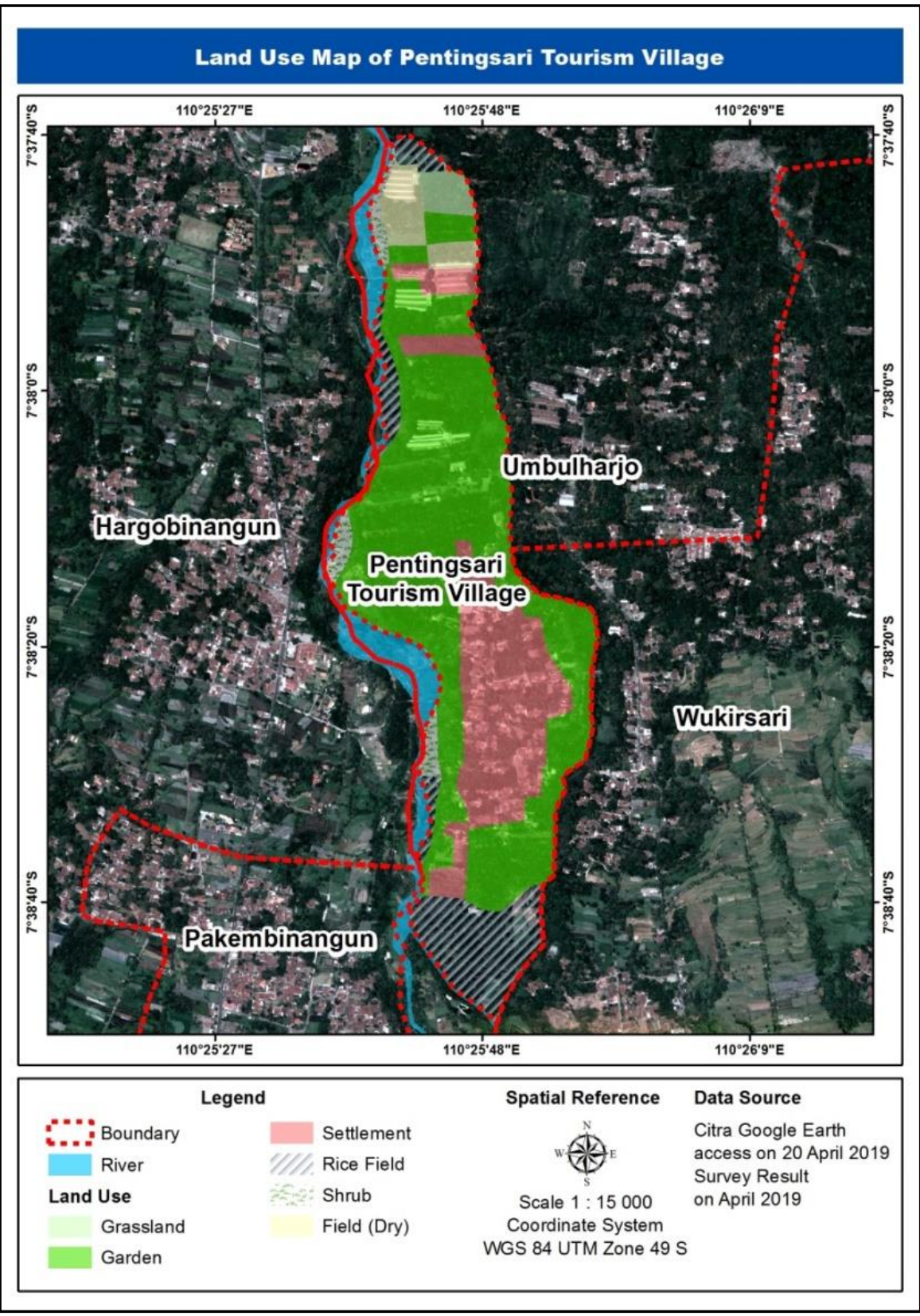

Gambar 3. Peta Penggunaan Lahan Desa (Sumber :Hasil Analisis, 2019)

Secara bentang alam, desa tersebut berbentuk semenanjung. Pada sisi Barat terdapat lembah curam Kali Kuning, disisi selatan lembah berupa gua Ledok atau Ponteng dan Gondoran. Sisi timur, lembah curam Kali Pawon dan sebelah utara merupakan dataran yang berhubungan langsung dengan tanah di sekeliling Kelurahan Umbulharjo tembus sampai ke pelataran Gunung Merapi

Metode pengambilan data aroma di desa wisata Pentingsari menggunakan sistem grid, dengan membagi wilayah desa ke dalam luasan yang sama. Sistem grid tersebut akhirnya menghasilkan 65 titik lokasi survei. Pengambilan data aroma, dilakukan sejak pagi hingga malam hari selama 3 hari. Aroma yang diamati kemudian dicatat pada form berisis titik koordinat, jenis 
dan ukuran (tinggi, sedang, rendah berdasarkan presepsi surveyor). Metode analisis data menggunakan analisis tetangga terdekat dioleh menggunakan software QGIS(Quantum GIS), seluruh data koordinat dipetakan sehingga diketahui pola sebaran bau di area desa.

\section{HASIL DAN PEMBAHASAN \\ Penggunaan Lahan}

Penggunaan lahaan di desa Wisata Pentingsari $66 \%$ didominasi oleh wilayah pertanian(lihat gambar 3), dimana pemanfaatan eksisting digunakan oleh warga sebagai area perkebunan, sawah dan peternakan warga. Wilayah permukimanterdapat di bagian tengah desa menuju selatan sebesar $19 \%$ dari luas kawasan. Pemanfaatan wilayah permukiman digunakan untuk rumah tinggal, homestay, area outbound, industri kerajinan, tempat ibadah, Joglo.

Tabel 1. Luas Penggunaan Lahan di Desa Wisata Pentingsari Tahun 2019 (Sumber: Hasil Analisis,2019)

\begin{tabular}{|c|c|}
\hline Penggunaan Lahan & Luas (Ha) \\
\hline Perkebunan/Kebun & 69.00 \\
\hline Tegalan/Ladang & 2.58 \\
\hline Sawah & 8.56 \\
\hline Permukiman dan Tempat Kegiatan & 20.00 \\
\hline Padang Rumput & 1.20 \\
\hline Semak Belukar & 1.92 \\
\hline Jumlah & 103.26 \\
\hline
\end{tabular}

Pola sebaran permukiman khusus untuk lahan budidaya khusus permukiman mengelompok di bangian tengah desa. Kawasan pertanian berada diseluruh wilayah desa, khusus untuk area persawasahan berada diselatan desa, sedangkan sempadan sungai berada disisi timur dan barat desa (Gambar 3).

\section{Wisatawan dan Homestay}

Wisatawan adalah sumber pendapatan bagi desa wisata Pentingsari. Kehadiran para wisatawan dapat meingkatkaan ekonomi masyarakat setempat lewat menginap dan mengikuti atraksi buatan yang sudah disediakan oleh pengelola desa wisata. Secara umum wisatawan di wilayah pentingsari berdasarkan hasil survei diperoleh 3 kategori diantaranya; pertama, berdasarkan asal terdiri dari wisatawan nusantara dan mancanegara. Kedua, wisatawan yang bertujuan untuk meneliti atau mengamati secara lebih detail terkait fenomena yang ada di desa Pentingsari.

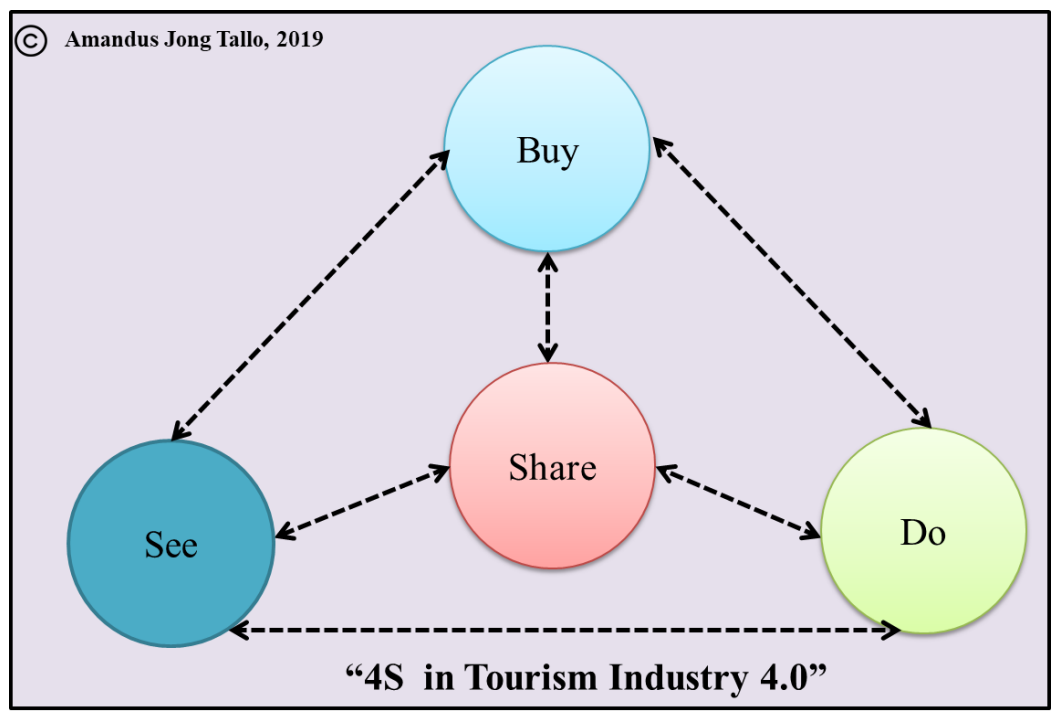

Gambar 4. Motivasi 4 S dalam Wisata 4.0 (Sumber :Hasil Analisis, 2019) 
Pada era 2019, pengembangan wisata tidak sebatas pada $3 \mathrm{~s}$ (something to buy, something to see, something to do), namun dalam industri 4.0 dimana internet menjadi kekuatan dalam penyebaran sistem informasi, maka penulis menemukan salah satau motivasi wisatawan adalah something to share. Pengalaman wisatawan berkunjung ke Pentingsari guna menddapatkan foto terbaik untuk dishare ke media sosial. Hal tersebut ditemukan pada saat mewawancarai Kopi Robusta hasil olahan kelompok Tunggak semi, dimana wisatawa datang hanya ingin menggoreng kopi hingga menghidangkan menjadi kopi yang siap diseduh.

Pengalaman akan aktivitas, juga dilakukan wisatawan pada saat membatik, menanam padi disawah, bermain gaamelan, menari, dan mengikuti atraksi-atraksi lain yang dibuat oleh pengelola wisata. Menurut Bapak Doto Yogantoroa(Ketua Desa Wisata Pentingsari), desa Pentingsari tidak menjual situs budaya, namun yang dijual adalah aktivitas, sehingga pengunjung diajak aktif mengikuti tradis masyarakat setempat, disamping itu alam di Pentingsari sama dengan desa wisata lain, namun aktivitas dan keramatamahan pengelola homestay yang menjadi andalan desa ini. Ketiga, adalah wisatawan yang menginap dan hanya sekedar mengunjungi desa.

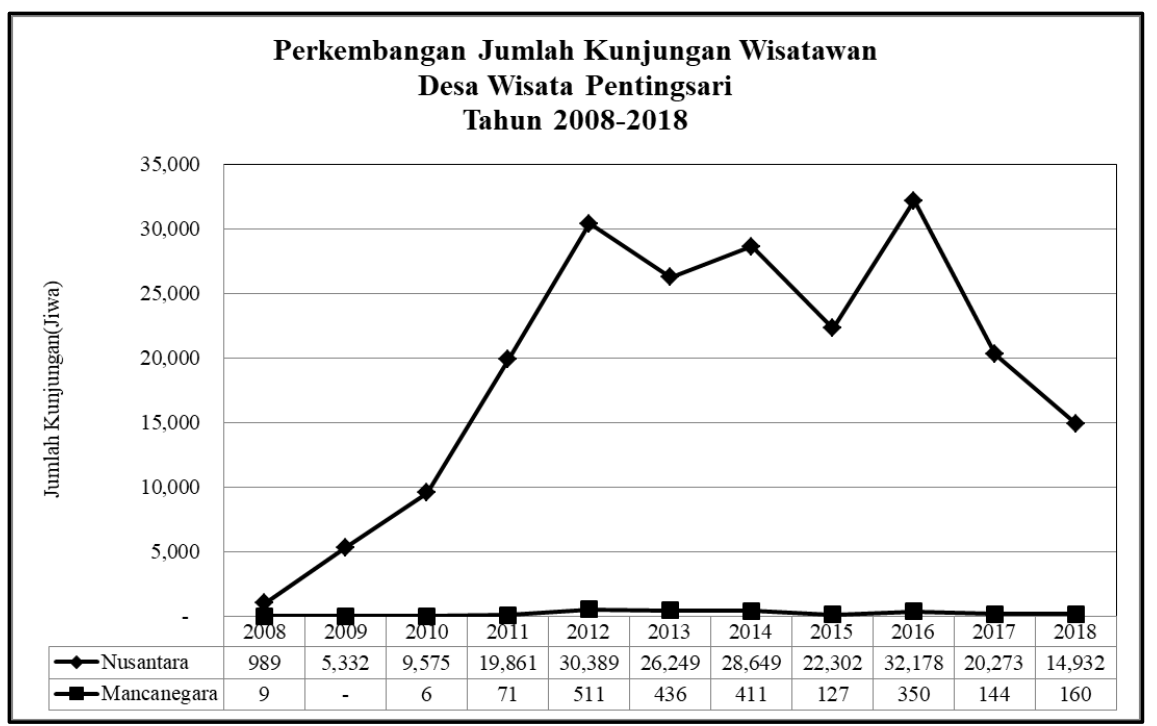

Gambar 5. Grafik Perkembangan Jumlah Kunjungan Wisatawan ke Desa Wisata Pentingsari Tahun 2008-2019 (Sumber: Analisis Peneliti,2019)

Selama 10 tahun terakhir(sejak 2008 hingga 2018), jumlah kunjungan terbesar berada di tahun 2016 sebesar 15,27\%, dan terkecil di tahun 2008 sebesar 0,47\%. Dari total wisatawan yang berkunjung, sebanyak $98,96 \%$ berasal dari wisatawan nusantara, sedangkan 1,04\% berasal dari wisatawan mancanegara. Jumlah wisatawan asing terbanyak berada pada 2012 sebesar 511 jiwa, dibandingkan waktu yang lain, salah satu faktor yang berpengaruh adalah pembangunan desa akibat gempa Merapi Oktober 2010, dimana menelan korban \pm 60 jiwa meninggal, $25 \mathrm{Ha}$ Area persawahan hilang, 2 jembatan putus, dan butuh 6 bulan untuk memperbaiki desa tersebut. Berdasarkan data tahun 2017, jumlah kunjungan tertinggi beada di bulan Desember seber 13,76 $\%$, sedangkan yang terendah pada bulan september sebesar 2,82 \% (Gambar 6).

Homestay merupakan rumah penduduk yang dijadikan tempat tinggal untuk wisatawan, sehingga wisatawan mendapatkan pengalaman dan mempelajari budaya(Eko Hari Parmadi, Anastasia Rita Widiarti, 2017). Keterlibatan masyarakat setempat sangat berpengaruh pada keberhasilan pemanfaatan homestay sebagai penunjang akomodasi di destinasi wisata(Mahadewi, 2018). Perkembangan jumlah rumah dan homestay di desa wisata pentingsari dari tahun ketahun semakin meningkat. Kenaikan jumlah homestay dimulai sejak 2010 hingga 2017. Ratio antara rumah dan homestay 1:2(rumah: kamar). Pada tahun 2010, selama 3 bulan sejak oktober hingga desember 30 rumah tidak melayani tamu dikarenakan erupsi merapi, hal ini juga berlaku selama 5 bulan di tahun 2011 bagi 40 rumah. 


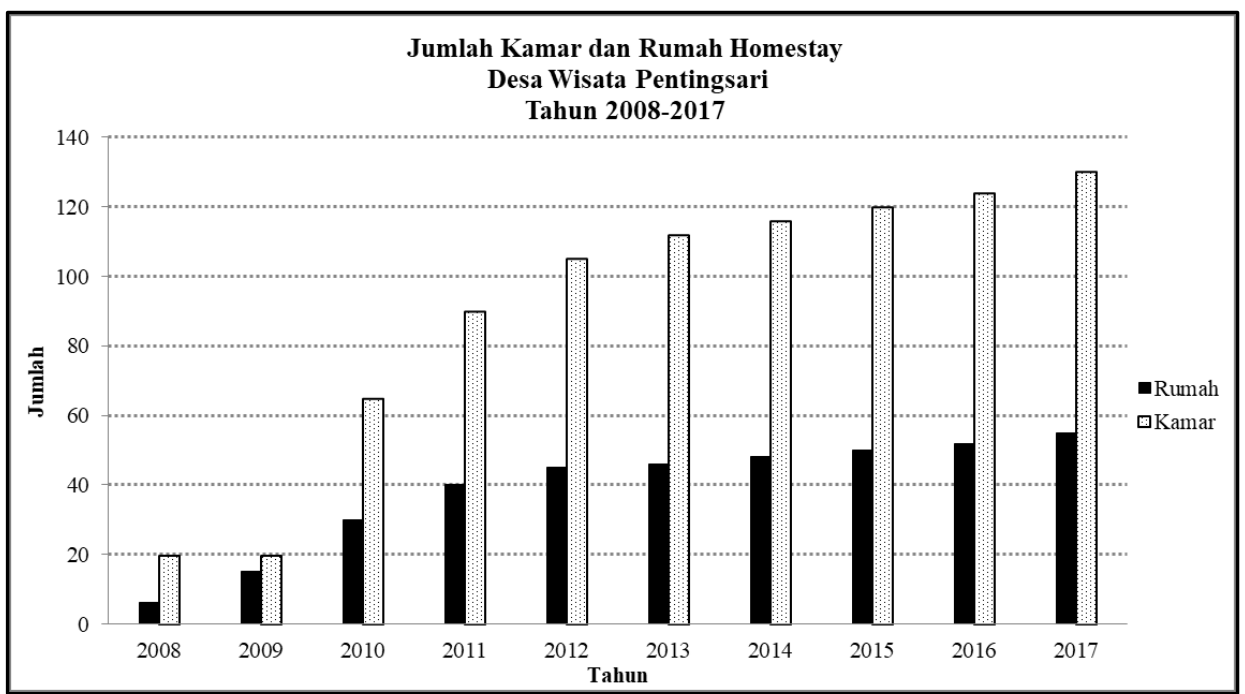

Gambar 6. Grafik Perkembangan Jumlah Kamar dan Rumah untuk Homestay di Desa Wisata Pentingsari Tahun 2008-2019 (Sumber: Analisis Peneliti,2019)

\section{Aroma di Desa Wisata Pentingsari}

Berbagai literatur pariwisata menyoroti bahwa pengalaman wisata harus didukung oleh elemen sensorik bukan hanya visual namun elemem penciuaman(Agapito, Pinto, \& Mendes, 2017). Efek dari aroma suatu tempat akan memberika keputusan bagi wisatawan untuk tinggal/ menetap sementara waktu atau akan kembali ke tempat yang sama dimasa mendatang(Vannini, Waskul, Gottschalk, \& Ellis-Newstead, 2012). Pengaruh dari tata guna lahan, geologi(tektur tanah dan batuan, bentang alam), dapat memberikan presepsi bagi wisatawan akan aroma yang ada di wilayah desa wisata Pentingsari. Pada sisisi lain kondisis iklim pada wilayah desa akan berpengaruh terhadap aroma yang muncul secara alamiah maupun buatan manusia.

Smellscape yang ada di Desa Wisata Petingsaiari terdiri dari bau alami seperti dari binatang ternak, tanah yang lembab, dan buah-buahan. Di kawasan utara terdapat bau kotoran hewan yang cukup tinggi dikarenakan terdapat kandang ayam skala dusun yang cukup besar, bau tersebut sangat kuat tercium ketika selesai musim hujan. Terdapat juga beberapa bau kotoran hewan selain ayam yaituntambing di bagian tengah desa, hal ini dikarenakan terdapat 5 kepala keluarga yang memihara kambing yang menyatu dengan permukiman. Umumumnyaa posisi kandang berada disamping rumah. Bau tanah sangat kuat, tersebar diseluruh area desa, terutama ketika pagi hari tanah masih berembun atau selepas hujan (Gambar 7).

Wilayah desa Pentingsari dilalui oleh sistem drainase yaang aktif (buatan), sehingga tanah di sempadan drainase terus lembab. Bau padi sawah berada di wilayah selatan desa perbatas dengan Desa Wukirsari, hal ini dikarenakan penggunaan lahan sawah seluas $20 \mathrm{Ha}$ dan aroma ini muncul karena saat panen tiba banyak tanaman padi yang dipanen oleh masyarkaat setempat. Aktivitas menanam padi merupakan salah satu atraksi desa. Wisatawan akan selalu mengingat bau sawah/padi pada saat beraktivitas disawah, selain itu padi di dusun pentingsari selalu ditanam setiap 3 bulan, selain sebagai lokasi atraksi juga digunakan untuk konsumsi sehari-hari. Aromo peohonan tersebar diseluruh wilayah desa memanjang dari utara hingga ke selatan, sehingga aroma pohon sangat mendominasi di desa (Gambar 8) 


\section{Smells Distribution Map of Pentingsari Tourism Vilage}
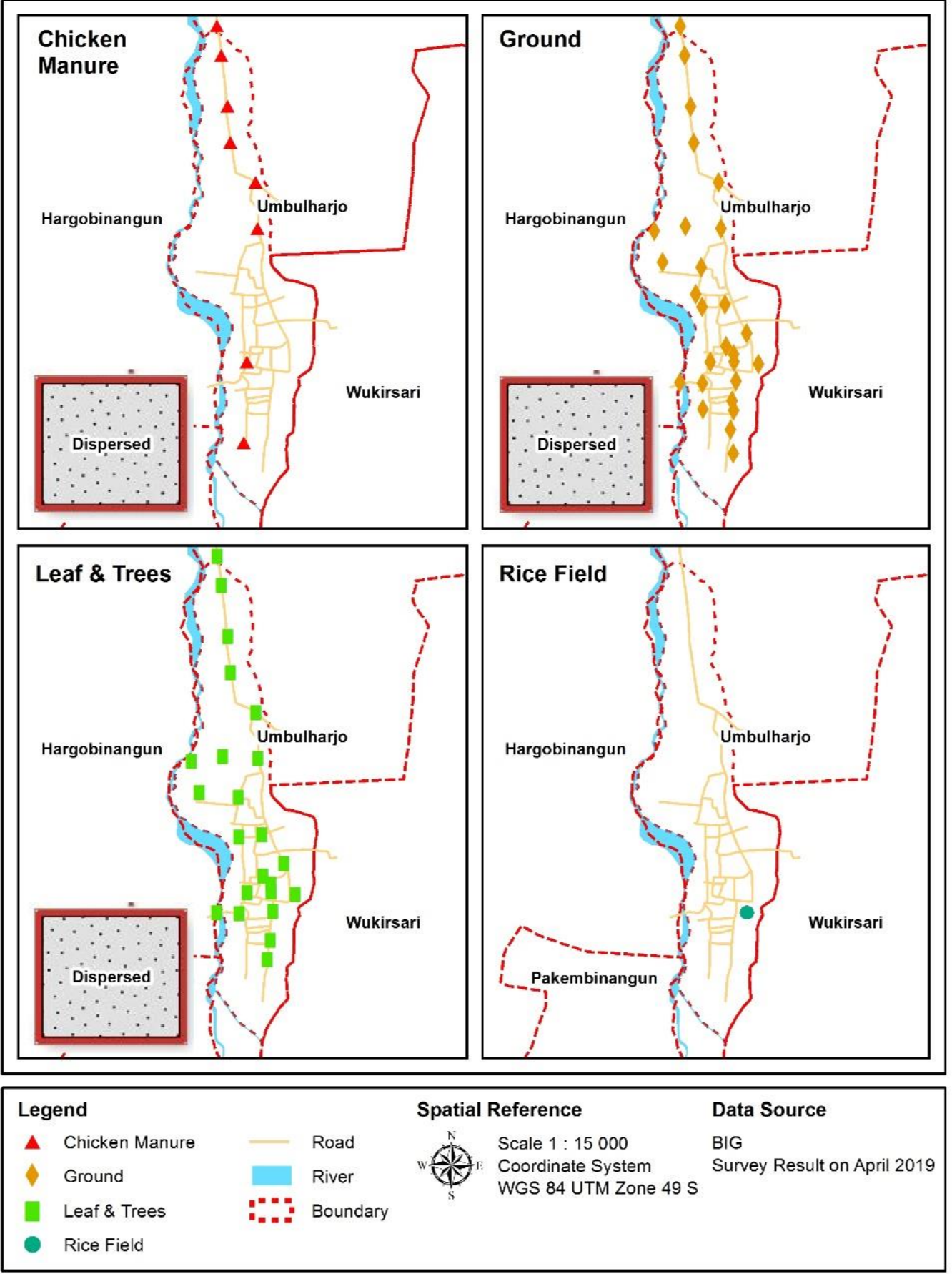

Gambar 7. Peta Persebaran Smellscape di Desa Wisata Pentingsari Tahun 2019 (Sumber: Analisis Peneliti, 2019) 


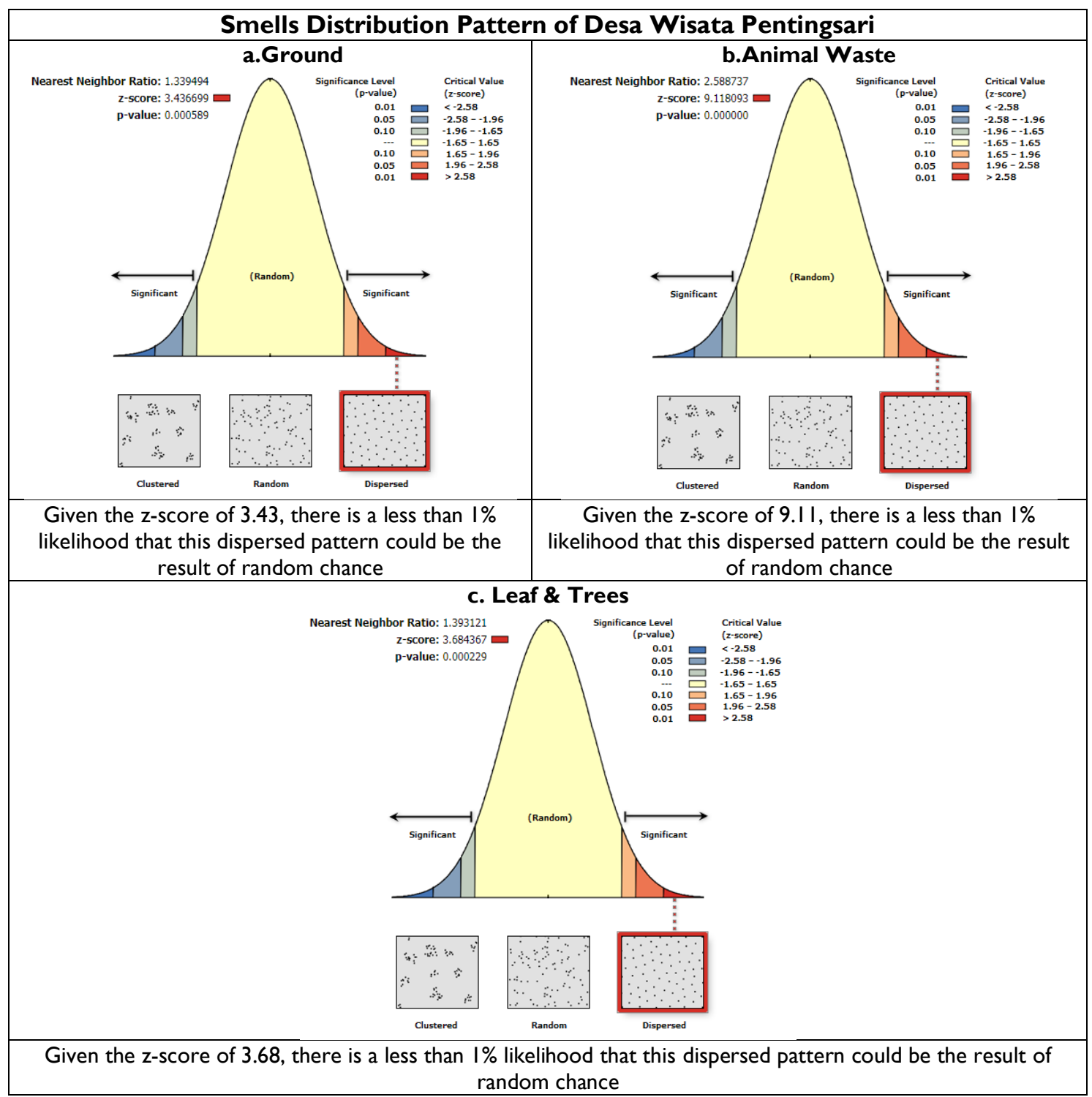

Gambar 8. Spatial Smells Distribution Pattern / Distinctive Sound of Pentingsari Tourism Village(Sumber: Peneliti, 2019)

Grafik 1 menunjukkan hasil analisis sebaran bau tanah, hasil analisis menunjukkan nilai $T$-score(indeks tetangga terdekat) 1,33 artinya pola sebaran bau tanah adalah acak di seluruh wilayah Desa Pentingsari, grafik 2 menunjukkan hasil analisis sebaran bau tanah, hasil analisis menunjukkan nilai T-score 2,56 artinya pola sebaran bau tanah adalah tersebar merata di seluruh wilayah Desa Pentingsari, sedangkan Bau tumbuhan dan pohon(c) m enunjukkan nilai T-score 1,39 adalah pola acak. Jika dirata-ratakan maka nilai rata-rata Aroma/bau di desa Pentingsari sebesar 1,76 tersebar secara acak dari utara hingga selatan desa.

\section{KESIMPULAN}

Berdasarkan hasil analisis diatas menunjukaan bahwa, penggunaan lahan sangat mempengaruhi sumber bau yang ada di wilayah desa wisata Pentingsari. Wilayah pertanian mendominasi area desa sebesar $60 \%$ dari 103 Ha. Terdapat 3 sumber bau diantaranya Bau Tanah, bau kotoran hewan./ternak dan bau Pohon, Padi/sawah. Bau Tanah dan pohon terbedar secara acak mulaipada seluruh wilayah desa. Bau Kotoran hewan(ayam), hanya berada di utara dan selatan desa, sedangkan bau sawah/padi berada di wilayah selatan desa(hanya 1 titik). Rata-rata pola penyebaran berdasarkan analisis tetangga terdekat berada pada nilai T 1,76 menunjukan pola penyebaran bau secara acak. 


\section{DAFTAR PUSTAKA}

Agapito, D., Pinto, P., \& Mendes, J. (2017). Tourists' memories, sensory impressions and loyalty: In loco and post-visit study in Southwest Portugal. Tourism Management, 58, 108-118. https://doi.org/https://doi.org/10.1016/j.tourman.2016.10.015

Agung, Rudi Budi, P. R. P. (2019). Prototipe Sistem Informasi Pemetaan Objek Pariwisata Menggunakan Framework Code Igniter Di Propinsi Jakarta. Jurnal GERBANG, $9(1$ Februari), 55-60. Retrieved from http://jurnal.stmik.banisaleh.ac.id/index.php/JIST/article/view/67

Anam, K., \& Hartono, O. D. (2019). Aplikasi Pemandu Pencarian Wisata Terdekat Berbasis GIS Android Dengan Algoritma Dijkstra. Jurnal Sains Komputer \& Informatika (JSAKTI), 3, 91-99. https://doi.org/http://dx.doi.org/10.30645/j-sakti.v3i1.99

Budiarti, Rike Limia, W. A. (2019). Pemanfaatan Google Maps API dalam Pemetaan dan Pemberdayaan Pariwisata Desa Di Indonesia Berbasis Web-Mobile. Indonesian Journal of Computer Scienc, 8(1), 55-65. Retrieved from http://ijcs.stmikindonesia.ac.id/index.php/ijcs/article/view/163

Eko Hari Parmadi, Anastasia Rita Widiarti, P. S. A. (2017). Pengelolaan Homestay Desa Wisata Pentingsari Berbasis Web. In H. F. Prof. Agus HArtoko, Subriyer Nasir, Refdinal Nazir (Ed.), Prosiding Seminar Nasional 2017, Penelitian dan Pengabdian Masyarakat; "Inovasi Riset dan Teknologi Terapan Untuk Mendukung Pembangunan Berkelanjutan" (pp. 386-3990). Pangkal Pnang: Universitas Bangka Belitung.

Fauzy, A., \& Putra, A. S. (2015). Pemetaan Lokasi Potensi Desa Wisata di Kabupaten Sleman Tahun 2015. Jurnal Inovasi Dan Kewirausahaan, 4(2), 124-129.

Gorman, R. (2017). Smelling therapeutic landscapes: Embodied encounters within spaces of care farming. Health \& Place, 47, 22-28. https://doi.org/https://doi.org/10.1016/j.healthplace.2017.06.005

Lestari, G., \& Armawi, A. (2016). Partisipasi Pemuda Dalam Mengembangkan Pariwisata Berbasis Masyarakat Untuk Meningkatkan Ketahanan Sosial Budaya Wilayah ( Studi di Desa Wisata Pentingsari , Umbulharjo , Cangkringan, Sleman ,. Jurnal Ketahanan Nasional, 22(2 Agustus), 137-157. https://doi.org/https://doi.org/10.22146/jkn.17302

Low, K. E. Y. (2015). The Sensuous City: Sensory Methodologies In Urban Ethnographic Research. Ethnography, 16(3), 295-312. https://doi.org/10.1177/1466138114552938

Mahadewi, N. M. E. (2018). Homestay Mozaik Pariwisata Berbasis Kerakyatan. In EDUTOURISM, TEKNOLOGI DAN HIBURAN DALAM PENGEMBANGAN HOMESTAY YANG BERBASIS MASYARAKAT LOKAL DAN BERKELANJUTAN (pp. 53-57). Bali: Sekolah Tinggi Pariwisata Nusa Dua Bali.

Meilan, Y. C. P. (2016). Identifikasi Aspek Sumber Daya Manusia Pariwisata Subsektor Perhotelan di Tangerang Berdasarkan Persepsi Wisatawan Generasi Milenial. In Conference on Management and Behavioral Studies (pp. 112-126). Jakarta: Universitas Tarumanegara.

Ni Ketut Pradani Gayatri S, Githa, Dwi Putra, I. P. A. (2018). Sistem Informasi Geografis Rekomendasi Objek Wisata Bali Menggunakan Metode TOPSIS. Jurnal MERPATI, 6(2 Agustus), 96-107. Retrieved from https://ojs.unud.ac.id/index.php/merpati/article/view/45441

Quercia, D., Schifanella, R., Aiello, L. M., \& McLean, K. (2015). Smelly Maps: The Digital Life of Urban Smellscapes. Association for the Advancement of Artificial Intelligence (Www.Aaai.Org), 1-18. Retrieved from https://www.aaai.org/ocs/index.php/ICWSM/ICWSM15/paper/view/10572/10516

Rina Firliana, Patmi Kasih, A. S. (2019). Pemanfaatan GIS Untuk Sistem Informasi Pariwisata. Nusantara of Enginering, 3(3), 1-12. Retrieved from http://ojs.unpkediri.ac.id/index.php/ti/article/view/245/170

Santoso, Sugeng, Ilamsyah, Ilamsyah, Abilaji, R. (2019). Padu Lokasi Wisata Kota Tangerang dengan Sistem Informasi Geografis Berbasis Web. Jurnal SIMIKA, 2(1), 1-11. Retrieved from http://ejournal.lppm-unbaja.ac.id/index.php/jsii/article/view/335

Sri Rahayu Budiani, Windarti Wahdaningrum, Dellamanda Yosky, Eline Kensari, Hendra S Pratama, Henny Mulandari, Heru Taufiq Nur Iskandar, Mica Alphabettika, Novela 
Maharani, Rizka Fitria Febriani, Y. K. (2018). Deteksi Luasan Mangrove Teluk Youtefa Kota Jayapura Menggunakan Citra Analisis Perubahan Potensi dan Strategi Pengembangann Pariwisata Berkelanjutan Berbasis Komunitas Landsat Multitemporal. Majalah Geografi Indonesia, 32(2), 170-176. https://doi.org/10.22146/mgi.

Sucipto, A. (2019). Strategi Kelembagaan Dalam Kompetisi Pariwisata : Pembelajaran Dari Desa Pentingsari Institutional Strategies In Tourism Competition : A Lesson From Pentingsari Village. Jurnal Ilmu Sosial MAHAKAM, 8(1), 1-14.

Sugiharto, F. D., \& Tumiar, S. (2019). The Spatial Distributionof Tourist Sites in Samosir, North Sumatera. Journal of Disaster, Geography and Geography Education, 3(1 June), 19. https://doi.org/https://doi.org/10.24036/sjdgge.v3i1.188

Vannini, P., Waskul, D., Gottschalk, S., \& Ellis-Newstead, T. (2012). Making Sense of the Weather: Dwelling and Weathering on Canada's Rain Coast. Space and Culture, 15(4), 361-380. https://doi.org/10.1177/1206331211412269

Vitasurya, V. R., Hardiman, G., \& Sari, S. R. (2012). Geographical Conditions And Cultural Tradition As Determinants In Sustaining Tourism Village Program Case Study Tourism Villages In Yogyakarta. International Journal on: The Academic Research Community Publication, 2(2), 1-9. https://doi.org/10.21625/archive.v2i2.240

Vitasurya, V. R., Pudianti, A., Purwaningsih, A., \& Herawati, A. (2014). Model alternatif pengelolaan limbah sampah sebagai dampak aktivitas wisata di desa wisata Pentingsari, Yogyakarta. Yogyakarta. 